\title{
Cultural memory and identity in the context of war: Experiential, place-based and political concerns
}

\section{Danielle Drozdzewski, Emma Waterton and Shanti Sumartojo}

Danielle Drozdzewski is a Senior Lecturer in Geography in the Department of Human Geography, Stockholm University. She has published extensively on the intersections of memory, identity and place, especially within the context of commemoration of war and violence. She is currently co-authoring "Digital Commemoration: Anzac @ 100" with Shanti Sumartojo and Emma Waterton.

Emma Waterton is a Professor in the Geographies of Heritage at Western Sydney University. She is the author and editor of over twenty academic books, including the co-edited volume Memory, Place and Identity: Commemoration and Remembrance of War and Conflict (with Danielle Drozdzewski and Sarah De Nardi), published in 2016 by Routledge.

Shanti Sumartojo is an Associate Professor of Design

Research at Monash University and an Adjunct in the School of Media and Communication at RMIT University. She has written extensively about commemoration and memory sites, including the recent co-edited volume Commemorating Race and Empire in the First World War Centenary (2018) with Liverpool University Press and Presses Universitaires de Provence. 


\begin{abstract}
Remembrance of war and conflict exposes the intricate interweaving of cultural memory and identity. Nations commemorate war to link narratives of the past with the present. This linking creates shared national narratives that temporally reinforce identities across the geography of the nation and among diverse citizenry. In this paper, the authors turn their attention towards the experiential and placebased concerns of the politics of memory within the context of war. It is argued that through attentiveness to individual experience we can better understand how cultural memory is enveloped into constructions of identity and critique such constructions alongside official narratives.
\end{abstract}

Keywords: cultural memory, national identity, commemoration, politics of memory.

\title{
Introduction
}

Nation-based memories of war have long been linked to articulations of national identity, to patriotism and to efforts to sustain the importance of the past, both in a nation's present and in future-oriented notions of cultural and collective identity. ${ }^{1}$ War and conflict so often punctuate the continuity of a nation's memory timeline and leave memories of wounding, trauma and suffering, regardless of victory or defeat. These wounds are "felt" both in the material structures of a nation - in its buildings, artefacts and cityscapes ${ }^{2}-$ and in its psyche, or its sense of identity, its capacity for recovery and its empathy towards those who lost their lives. In cases of territorial subjugation, such wounds are particularly pronounced and often have extended longevity. Here, one need only think of the extent of post-socialist renaming of streets and towns or the public removal of statuary in the former Eastern Bloc to see our point. ${ }^{3}$ Yet beyond such impulses to remove material and physical reminders of occupation, intangible wounds remain inevitable. As Drozdzewski et al. argue, such memories of place, and the etching of identity in, on and to those places, ${ }^{4}$ seem always to simmer and potentially provide fuel for further conflict, as was the case in the 2014 Russian annexation of Crimea. Such examples make it clear that memory matters to our individual constructions of identity, as well as to constructions of collective national identity.

1 Ernest Renan, "What is a Nation?” (first published 1882), in Homi K. Bhabha (ed.), Nation and Narration, London, Routledge, 1990; Danielle Drozdzewski, Sarah De Nardi and Emma Waterton, "Geographies of Memory, Place and Identity: Intersections in Remembering War and Conflict", Geography Compass, Vol. 10, No. 11, 2016; Patrick Finney, "On Memory, Identity and War”, Rethinking History, Vol. 6, No. 1, 2001.

2 Robert Bevan, The Destruction of Memory: Architecture at War, Reaktion Books, London, 2006.

3 Maoz Azaryahu, "German Reunification and the Politics of Street Names: The Case of East Berlin", Political Geography, Vol. 16, No. 6, 1997.

4 Danielle Drozdzewski, Sarah De Nardi and Emma Waterton, "The Significance of Memory in the Present", in Danielle Drozdzewski, Sarah De Nardi and Emma Waterton (eds), Memory, Place and Identity: Commemoration and Remembrance of War and Conflict, Routledge, Abingdon, 2016, p. 3. 
In this paper, the nuanced ways in which cultural memory "matters" in different national contexts is explored. Drawing from the work of Astrid Erll, the authors treat cultural memory as encompassing notions of collective and social memory. Here, the "cultural" serves to embed memory in the practices, stories, myths, monuments, events, rituals and other configurations of cultural knowledge that weave together past and present amid their "socio-cultural contexts". ${ }^{5}$ In a rapidly changing world, where the incidences and implications of conflict show no sign of abatement, it is crucial to continue to probe at the nexus between memory and identity, and to interrogate not only how memory is used for political purposes but also how it extends far beyond normative materialities of memory, exemplified by monuments, memorials and museums.

Such explications are crucial not only for conceptualizing the nation, but also for becoming part of that nation and feeling a concomitant sense of belonging. Indeed, nations rely on memory to assert collective identity and strengthen national resolve. In other words, if "memory makes us what we are", ${ }^{6}$ one needs to look closely not only at the way national identities exercise elasticity and stretch, but also at how they are deliberately plied. Amid the (frightening) global momentum for nations to look inward and exclude difference, and for fear of the other to predicate how national identities are evolving in an era of global mobility, studies focused on memory tell us about much more than who we were in the past. This paper contends that such studies tell us what we can be in the future, why, and what political decisions and resources can be mustered to support different visions or versions of identity. Moreover, how calls to action that use memory are framed, the terms in which memory is manifested and described, and the empirical and conceptual location of memory can all shape what cultural memory means, how it matters and what it does.

From the perspective of geography, memory is understood as being firmly grounded in its links to place and identity, but also to the role of power in representations of memory. By attending to the politics of memory, we can apprehend not only how power impacts and influences the experience of representations of memory, but also how it affects the (re)production, maintenance and performance of identity. While explorations of the politics of memory are hardly new, this paper's orientation towards the experiential, sensory and emergent distinguishes it from other scholarship investigating the nexus of memory and identity. By focusing on memorial sites, events and the everyday, the authors show how a focus on how people experience, understand and make sense of the narratives promulgated by the State can illuminate where these

5 Astrid Erll, "Cultural Memory Studies: An Introduction", in Astrid Erll, Angsar Nunning and Sara B. Young (eds), Cultural Memory Studies: An International and Interdisciplinary Handbook, DeGruyter, Berlin, 2010, pp. 1-2. See also Ann Rigney, "Cultural Memory Studies: Mediation, Narrative and the Aesthetic", in Anna Lisa Tota and Trever Hagen (eds), Routledge International Handbook of Memory Studies, Routledge, Abingdon, 2015; Lucy Bond, Stef Craps and Pieter Vermeulen (eds), Memory Unbound: Tracing the Dynamics of Memory Studies, Berghahn Books, New York, 2017.

6 Owain Jones, "Geography, Memory and Non-Representational Geographies”, Geography Compass, Vol. 5, No. 12, 2011, p. 875. 
narratives might likely be transformed or used to particular political ends. In short, the paper argues that by attending to experience, we can gain new insight into how memory and identity fold together, with a fresh perspective on the resulting political implications.

Following an introduction to the politics of memory, three thematic sections will present an assemblage of viewpoints through an experiential lens. First, the location of memory will be explored through an examination of the official memorial sites associated with Pearl Harbor in the United States. Building on this, the article will touch upon the event of memory by exploring ceremonies that commemorate conflict, drawing out a range of experiential aspects that shape how societies make sense of these moments. The penultimate section focuses on memory's spatiality, paying particular attention to the everyday landscapes of memory that intersect with daily routines. The sections below investigate the ways in which memory becomes a part of our experiential worlds, illustrating the details of how memory is expressed, felt and experienced.

\section{Memory and its politics}

Tosh has argued that moments chosen as symbolic to the nation work to confirm both self-image and group aspirations. ${ }^{7}$ Instrumental in this process of "choosing moments" are attempts to connect the past to the present by creating a milieu of shared historical consciousness through which representations of the past are deemed of importance to the collective present. Further, Osborne has argued that public monuments often act as "consensus builders", thereby becoming "focal points for identifying with a visual condensation of an imagined national chronicle rendered in heroic symbolism". ${ }^{8}$ Such focal points are important sites from which national identities are scaffolded; they are not merely the material and everyday backdrop of the urban facade but are an integral part of a nationbuilding agenda. Ewa Nowicka-Rusek and Ayur Zhanaev provide a clear example of this in the form of contemporary nation-building by the Buryats (Siberia), who draw heavily on the figure of Genghis Khan in public monuments, films, TV series and songs to communicate a sense of strength and cultural maintenance. ${ }^{9}$

Accordingly, memories of nation are stories of the past specifically chosen by the State to impart a certain version of a nation's past to the public. Because these State-led memory narratives are not experienced by all individuals in the same way, the State uses prompts to create, and then invoke, memory narratives of nationbased events; for example, specific dates and the form of commemoration for a historical event are chosen (such as Remembrance Day in the United Kingdom), and streets are named for significant people, places or events (such as those

7 John Tosh, In Pursuit of History, Longman Press, London, 1991, p. 2.

8 Brian S. Osborne, "Landscapes, Memory, Monuments, and Commemoration: Putting Identity in its Place", Canadian Ethnic Studies, Vol. 33, No. 3, 2001, p. 50.

9 Ewa Nowicka-Rusek and Ayur Zhanaev, "The Image of Genghis Khan in Contemporary Buryat Nation Building", Polish Sociological Review, No. 187, 2014. 
named for Martin Luther King in the United States). Decisions about such symbols are executed by people in power and, as they are often not made without a struggle, comprise a politics of memory. ${ }^{10}$ Rusu has argued that a politics of memory involves the use of political strategies to come to terms with the past. ${ }^{11}$ The use of memory in national discourse also builds continuity: memory links past to present because, as MacDowell argues, "without memory, a sense of self, identity, culture and heritage is lost". ${ }^{12}$ Moreover, as Graham Smith contends, "[c]ontinuity is the socially constructed sense that a group has a relatively consistent connection between its past and present". ${ }^{13}$ This sense of continuity, whether real or imagined, is a key component of the politics of memory.

Critically, processes of identifying or creating national memories invoke the senses. This aligns with approaches in memory studies that identify how important sensorial cues are for making memories stick with us. As Drozdzewski et al. have argued, "a smell, a familiar touch, an image, a sound once heard before can transport us not only to different times but also different places". ${ }^{14}$ At a routine level, then, memory is "a highly important element in the account of what it is to be a person, as it is the central medium through which identities are constituted". ${ }^{15}$ These intimate experiential memories become part of how we define not only ourselves, but where we have been and with whom. Via similar sensorial prompts, memory narratives championed by State authorities permeate public spaces and everyday lives to shape how national identity feels as much as how it is understood. ${ }^{16}$ This experiential, sensory "everyday nationhood" is evidenced in the sight of national buildings or monuments, the sound of music such as national anthems or public broadcaster themes, and the flavours of cuisines identified as specifically national. ${ }^{17}$ Conflicts over the latter in relation to their inscription on the Representative List of UNESCO's Convention for the Safeguarding of the Intangible Cultural Heritage are a case in point-fierce disputes over national ownership have ensued, for example, between Turkey and Armenia due to the inscription of the dish keşkek, prepared from meat and

10 D. Drozdzewski, S. De Nardi and E. Waterton, above note 1; Andreas Huyssen, Present Pasts: Urban Palimpsests and the Politics of Memory, Stanford University Press, Stanford, CA, 2003; Katharyne Mitchell, "Monuments, Memorials and the Politics of Memory", Urban Geography, Vol. 24, No. 5, 2003; Berber Bevernage and Nico Wouters (eds), The Palgrave Handbook of State-Sponsored History after 1945, Palgrave Macmillan, London, 2018.

11 Mihai Stelian Rusu, "Transitional Politics of Memory: Political Strategies of Managing the Past in PostCommunist Romania", Europe-Asia Studies, Vol. 69, No. 8, 2017.

12 Sara McDowell, Heritage, Memory and Identity: The Ashgate Research Companion to Heritage and Identity, Ashgate, Aldershot, 2016, p. 42.

13 Graham Smith, "Nation", in Ron J. Johnston, Derek Gregory, Geraldine Pratt and Michael Watts (eds), Dictionary of Human Geography, 4th ed., Blackwell, 2000, Oxford, p. 532.

14 D. Drozdzewski, S. De Nardi and E. Waterton, above note 4, p. 1.

15 Barbara Misztal, Theories of Social Remembering, Open University Press, Maidenhead, 2003, p. 1.

16 Michael Billig, Banal Nationalism, SAGE Publications, London, 1995.

17 Michael Skey and Marco Antonsich (eds), Everyday Nationhood: Theorising Culture, Identity and Belonging after Banal Nationalism, Palgrave Macmillan, Basingstoke, 2017. 
crushed wheat, on behalf of Turkey in 2011, despite opposition from Armenia, which also claims links to the dish's origins. ${ }^{18}$

\section{Remembering in place}

Many types of memoryscapes can, and often are, captured within the rubric of "heritage". These include burial sites, battlefields and memorials dedicated to wars, as well as other events such as those created at the perimeter of Ground Zero, Manhattan, in the immediate aftermath of $9 / 11 .{ }^{19}$ While numerous memoryscapes are created to commemorate or celebrate a sense of achievement, many are established to honour, remember or justify political acts, such as the Vietnam Veterans Memorial in Washington, DC, or the Australian War Memorial in Canberra. These places might be referred to as sites of "dissonant" or "difficult" heritage, as places that open up dark or painful histories and foreground the politics of the past in the present. ${ }^{20}$ Much has been written about such places and the connections they have with cultural memory and identity, particularly from post-structural perspectives. ${ }^{21}$ Such scholarship has done important work in uncovering the relations of power implicated in any attempt to represent the past, and in revealing implicit political meanings and associated processes of marginalization. Relatedly, this literature has also explored the many instances in which memorials and heritage sites have been mobilized to invoke agitations against domination, such as in post-conflict struggles over recognition and reconciliation. Clear evidence of this can be seen in the flurry of active memorial-making in post-Soviet Mongolia, or the purging of Soviet monuments following the collapse of communist control in places like Georgia, Uzbekistan and Tajikistan. ${ }^{22}$ Other examples within this mix are official locations of remembrance such as national museums, memorials and monuments.

As Jay Winter has argued, these sorts of sites, often located in symbolic settings, are "places where groups of people engage in public activity through which they express 'a collective shared knowledge' ... of the past, on which a

18 Bahar Aykan, "The Politics of Intangible Heritage and Food Fights in Western Asia”, International Journal of Heritage Studies, Vol. 22, No. 10, 2016.

19 Joy Sather-Wagstaff, Heritage that Hurts: Tourists in the Memoryscape of September 9/11, Left Coast Press, Walnut Creek, CA, 2011.

20 Gregory Ashworth and John Tunbridge, Dissonant Heritage: The Management of the Past as a Resource in Conflict, John Wiley \& Sons, Malden, MA, 1996; Steven Cooke and Donna-Lee Frieze, "Affect and Politics of Testimony in Holocaust Museums", in Divya Tolia-Kelly, Emma Waterton and Steve Watson (eds), Heritage, Affect and Emotion: Politics, Practices and Infrastructures, Routledge, Abingdon, 2017.

21 Emma Waterton and Steve Watson, The Semiotics of Heritage Tourism, Channel View Publications, Bristol, 2014. See also S. Cooke and D.-L. Frieze, above note 20; Joy Sather-Wagstaff, "Making Polysense of the World", in D. Tolia-Kelly, E. Waterton and S. Watson (eds), above note 20; Mattias Frihammer and Helaine Silverman (eds), Heritage of Death: Landscapes of Emotion, Memory and Practice, Routledge, Abingdon, 2018.

22 Alexander C. Diener and Joshua Hagen, "From Socialist to Post-Socialist Cities: Narrating the Nation through Urban Space", Nationalities Papers: The Journal of Nationalism and Ethnicity, Vol. 41, No. 4, 2013. 
group's sense of unity and individuality is based". ${ }^{23}$ Moreover, such places of memory are key materialities in the wider processes of nation-building. ${ }^{24}$ Dealing as they do with collective memories, or "what remains of the past in the lived experience of groups", 25 such memorials and museums are necessarily imbued with messages and meanings that are social in origin and are embedded in a range of cultural, political and economic contexts. The memories they trigger and produce are thus also inflected with, and influenced by, language, rituals and commemorations, and perform in a variety of processes that make past events meaningful in the present.

Memorial landscapes such as Auschwitz-Birkenau Memorial and Museum, Hiroshima Peace Memorial Park and the Pearl Harbor memorial complex form a particular variant of this sort of "dissonant" or "difficult" heritage, in that they narrate the trauma of war in places that are built around the residual or material remains of conflict - memories literally etched into place. As reminders of pain and destruction, such sites, as Curti argues, are "always performed and felt between, in and through bodies and thus always work through entangled forces of emotion, affect and memory". ${ }^{26}$ As such, they hold particular sway in the imagination. Their evocative power lies in the links they are able to make between the physical spaces in which visitors stand and what is known to have happened there. The way such sites are officially framed and represented plays a significant part in the overall memorialization process, signalling at least part of the range of responses one might have when reflecting on the horrors of conflict and war.

However, as Curti claims, there are other responses at work too, and these are often more personal. Such responses are not immediately expressible but are deeply felt, physical and visceral, and emerge as visitors react to atmosphere and a sense of haunting in situ. The physicality of many heritage sites thus acts as an anchor between "now" and "then", and is perhaps best understood as a vector for feelings of identity and belonging, through which historical events come to have an enduring impact on our emotions and understanding. Such processes may be referred to as "embodied remembering" and point to the "experiential dimensions of memory". At the same time, it is important to be mindful of the risks of presentism in prioritizing the immediacy of the "here and now", which can, if left unchecked, diminish the importance of past experiences. ${ }^{27}$ Indeed, as Bergson has so powerfully argued, "[t]here is no perception which is not full of

23 Jay Winter, "Historians and Sites of Memory", in Pascal Boyer and James V Wertsch (eds), Memory in Mind and Culture, Cambridge University Press, Cambridge, 2009, p. 252.

24 Karen Till, "Places of Memory", in John A Agnew, Katharyne Mitchell and Gerard Toal (eds), A Companion to Political Geography, John Wiley \& Sons, Malden, MA, 2003.

25 Geoff Cubitt, History and Memory, Cambridge University Press, Cambridge, 2007, p. 10.

26 Giorgio Hadi Curti, "From A Wall of Bodies to a Body of Walls: Politics of Affect/Politics of Memory/ Politics of War", Emotion, Space and Society, Vol. 1, No. 2, 2008, p. 108.

27 E. Waterton and S. Watson, above note 21; Geoffrey White, "Epilogue: Memory Moments", Ethos, Vol. 34, No. 2, 2006. 
memories. With the immediate and present data of our senses, we mingle a thousand details out of our past experience." 28

\section{The heritage of Pearl Harbor}

To explore these processes in the context of war and cultural memory, one need only look to the memorial sites associated with the attack on Pearl Harbor of 7 December 1941. This case provides a powerful example of how some objects, people and places can grow "sticky" or saturated with affect, to borrow from Sara Ahmed - or, in other words, charged with meaning due to their associations with significant events. ${ }^{29}$ It is an example that also has strong echoes with Trigg's work on the memory of place, in which he considers the various ways in which materiality, or the incision of a monument within a landscape, interacts with "the making of memories" and the placing of "our own selves within relation to that past". ${ }^{30}$

The memoryscape of Pearl Harbor beautifully illustrates the pulsing relations between war, cultural memory and identity in its changing orientation to national memory. Pearl Harbor, as a memorial complex, is an important site of memory in the US context, where it has become the end destination for a significant secular pilgrimage. In this regard, it has an incredible spatial reach. A National Historic Landmark, with parts still operating as an active military base, the Pearl Harbor memorial complex is comprised of the Pearl Harbor Visitor Centre and USS Arizona Memorial, the USS Bowfin Submarine Museum and Park, the USS Missouri Memorial (affectionately named "the Mighty Mo") and the Pacific Aviation Museum. In addition, the complex includes a number of mooring quays that formed part of "Battleship Row" within the Harbor itself, six historic chief petty officer bungalows, the USS Utah Memorial and the USS Oklahoma Memorial, all of which are located on Ford Island. The narratives associated with Pearl Harbor draw explicitly on the Japanese attacks that mark the entry of the United States into the Second World War in 1941. On the morning of 7 December, just after 8 a.m., 183 fighters and torpedo bombers targeted the 185 vessels of the US Navy that were moored in Pearl Harbor, including seven battleships clustered together close to the eastern shoreline of Ford Island on "Battleship Row". Five of the battleships sank, and the other two were badly damaged. One, the USS Arizona, sank in nine minutes but burned for two days: 1, 177 servicemen died, leaving 337 survivors.

The first stirrings of an interest in preserving elements of the complex as a mode of remembrance emerged in 1949, with the establishment of the Pacific War Memorial Commission, which was followed by a Congress-endorsed authorization

28 Henri Bergson, Matter and Memory, Allen and Unwin, London, 1911, p. 24. See also Monica Degen and Gillian Rose, "The Sensory Experiencing of Urban Design: The Role of Walking and Perceptual Memory", Urban Studies, Vol. 49, No. 15, 2012.

29 Sara Ahmed, “Affective Economies”, Social Text, Vol. 22, No. 2, 2004.

30 Dylan Trigg, The Memory of Place: A Phenomenology of the Uncanny, Ohio University Press, Athens, $\mathrm{OH}$, 2012, pp. 82, 98 . 
to build a memorial to the USS Arizona almost a decade later. ${ }^{31}$ Its centrepiece, the 184-foot USS Arizona Memorial, designed by architect Alfred Preis to straddle the ship's sunken wreck, was opened to the public in 1962 - at the height of the Cold War. ${ }^{32}$ Initially operated by the US Navy, this early iteration of the memorial complex revolved around water transportation to and from the shoreline and the USS Arizona Memorial. In 1965, the naval base at Pearl Harbor was designated a National Historic Landmark, and from that point onwards visitor numbers steadily increased. The visitor centre opened in 1980, at which time the Navy handed over the management and organization of the site to the National Park Service, though it retained control over transportation to and from the USS Arizona Memorial. Shortly thereafter, in 1981, the USS Bowfin submarine arrived, effectively developing into the USS Bowfin Submarine Museum and Park by 1987. Just over a decade later, in 1998, the USS Missouri, recently decommissioned and struck from the Naval Vessel Register, was donated to the museum complex. In 2006, a final historic site was added with the Pacific Aviation Museum, which includes two of the original aeroplane hangars and the Ford Island Control Tower, all three of which were in operation in 1941. There is no shortage of remains left in place at Pearl Harbor that may serve as reminders of trauma.

The authors' interest in Pearl Harbor lies in its ability to illustrate the power of places to "gather, attracting people, memories and affects" around them, or to operate as what Gaston Gordillo has described as a "bright object". ${ }^{33}$ In using this term, Gordillo is referring to the ability of some things, people or places to "attract because of the way they relate to other subjects". ${ }^{34}$ Pearl Harbor offers a clear illustration of the way an object of war can, and often does, become an object of memory, not only because it has a resilient gravitational pull and affective intensity, but because it is also used to define the meaning of other objects and events in its vicinity. ${ }^{35}$ For instance, Pearl Harbor's "brightness" may have diminished in recent years were it not for the occurrence of 9/11, which brought renewed focus - nationally and internationally - to American wartime history and memories. Significantly, these two events represent the only times the nation has been attacked on its own soil, such that the 9/11 attack prompted those places associated with the Pearl Harbor attack to re-emerge as key reference points for both the media and the public. $^{36}$ The release of the Hollywood blockbuster Pearl Harbor in 2001 similarly pierced the popular imagination,

31 Emily Rosenberg, "Commemoration of Sacrifice", in Emily Rosenberg (ed.), A Date Which Will Live: Pearl Harbor in American Memory, Duke University Press, Durham, NC, 2003; Geoffrey M. White, "Disney's Pearl Habor: National Memory at the Movies", The Public Historian, Vol. 24, No. 4, 2002.

32 Robin Gerster, "On the War Path", Eureka Street, Vol. 11, No. 1, 2001; Yujin Yaguchi, "War Memories Across the Pacific: Japanese Visitors at the Arizona Memorial", in Marc S. Gallicchio (ed), The Unpredictability of the Past, Duke University Press, Durham, NC, 2007.

33 Gaston R. Gordillo, Rubble: The Afterlife of Destruction, Duke University Press, Durham, NC, 2014, p. 22.

34 Ibid.

35 Ibid.

36 Geoffrey M. White, "Pearl Harbor and September 11: War Memory and American Patriotism in the 9-11 Era", The Asia-Pacific Journal, Vol. 1, No. 4, 2003. 
working to ensure that visitors would continue to actively seek out its memorial spaces, which currently attract some 1.8 million visitors a year.

In addition to their ability to "pull" other objects and meanings to them, memorial sites like Pearl Harbor have the benefit of allowing visitors to see and feel history in context and on site, which is an important component of the war/ memory dyad. However, this pull factor is not a nod to the importance of "authenticity". Rather, it inflects and references a site's ability to conjure up feelings of "being there", or put another way, authentic feelings. At Pearl Harbor, the ability to enter the USS Bowfin submarine is vitally important, as is standing above the USS Arizona or gazing down on the Surrender Deck of the USS Missouri-all three examples give a sense of space, confinement, touch, silence, claustrophobia and helplessness. Interestingly, the USS Bowfin was not moored in Pearl Harbor during the attacks themselves - it was launched into service precisely one year later. But the opportunity to board a submarine that was in service during the war, one that is now moored within the historic memoryscape of Pearl Harbor, is for many visitors a crucial experience. The concept of "authenticity", then, plays a fluid and changing role in processes of memory: the materiality of the submarine is "real", but the location itself is something of a necessary surrogate.

This observation allows us to extend our thinking towards affective capacities - what a body is capable of feeling and doing. This is a notion positioned somewhere in between human and non-human agents, and it effectively blurs the boundaries between them. The memoryscape of Pearl Harbor provides an illustration of the way memory-work is contingent upon a visitor's own histories and memories, the nuances of their personalities, social positions, cultural affiliations and ethnic backgrounds, and the discursive realms within which they operate and to which they respond. But it also confirms that such processes of memory-making are contingent not only on the human. The affective capacities of the Pearl Harbor memorial complex push forward a narrative of the past that is almost entirely American and based on narratives of warfare and nationalism. In this, the memorial becomes a clear component of a wider political project: its narratives are consumed by an overwhelmingly American audience, a significant portion of which, as research has shown, feels compelled to visit Pearl Harbor as a way of performing their own individual national duty. ${ }^{37}$ In other words, they have the capacity to be affected in very particular ways, and thus come to know and connect with the nation through their visit in ways that revolve around acknowledging sacrifice and subsequent military action or service. This ability to know and remember the history of Pearl Harbor is particularly expressed in an apparent contradiction: the unimaginability of the attacks together with the violence, suffering and visceral horror, and at the same time the idea of a connection, or an identification of the subjective 
experience that is activated and energized by the affective and emotional motilities that the non-human site and its human event engender together.

The relative "brightness" of sites such as Pearl Harbor lies in their ability to speak to, and in many cases (re)affirm, a sense of both personal and national identity. Moreover, it is the process of "being there", in place, coupled with the visceral sensations of pride and honour that are produced there, that particularly thickens the site's capacity to move and affect, which in turn lends it the ability to "weigh on" and intersect with a variety of visitors as they move around the complex. In the next section, these relations are explored through the act of commemoration.

\section{Commemorative events}

Given that heritage sites such as those associated with Pearl Harbor play a vital role in how the relationship between memory and collective identity is understood, the regular use and animation of such places through commemorative events is crucial. In this section, the authors consider memory and identity by way of regular commemorative events, and the collective and experiential analytical orientations that investigating them affords. These are rituals on a predictable, often annual schedule, of which many people have foreknowledge and previous experience, and that are intended to reinforce particular narratives of group memory and renew the connection of individuals to those narratives and to each other. Moreover, these events often carry particular sensorial and material aspects that are central to how they are experienced and what meanings they carry. Memorial or heritage sites, as discussed above, are spaces redolent with representative symbols, which also often invite or compel us to engage with them bodily in particular ways, such as tilting our heads to look up at their statues or displays or walking quietly through their hushed, reflective spaces. ${ }^{38}$ When these sites are activated by a commemorative ritual, elements such as music, artificial and natural light, weather, gatherings and the recitation of well-known texts temporarily transform them into significant and atmospheric places which do particular forms of work in terms of memory and identity. Accordingly, in this section the authors will focus on commemorative events' regular nature, which builds accreted foreknowledge and anticipation for individuals whilst also reinforcing the events' importance in the public imagination. Next, the opportunities such events provide for widespread reflection, conversation and debate about group identity, as well as their inherently collective character, will be explored.

Wagner-Pacifici speaks of a reimagined version of the event in which commemoration can be thought of as a "provisionally congealed moment" of the

38 Shanti Sumartojo, "On Atmosphere and Darkness at Australia's Anzac Day Dawn Service", Visual Communication, Vol. 14, No. 2, 2015; Shanti Sumartojo, "Commemorative Atmospheres: Memorial Sites, Collective Events and the Experience of National Identity", Transactions of the Institute of British Geographers, Vol. 41, No. 4, 2016. 
occasion that it seeks to reinforce in collective memory. ${ }^{39}$ In her example, the $9 / 11$ terrorist attacks in the United States must be understood as having subsequently moved "beyond the initial stage of incoherence, rupture, and surprise" to be sedimented in official forms that include memorials and that have become "part of the event itself as it lives on in intermittently tamped down and restless modes". ${ }^{40}$ What is important about the relationship between memory, identity and how they are taken up and understood by way of experience is her point that in remembering events, we must grapple with their restless and mutable nature the fact that they come to take on new meanings and change in significance over time. ${ }^{41}$ This point is pragmatic because, as will be discussed below, a focus on commemorative events demands that not only their regular rhythms and familiar discursive elements are attended to, but also their contingency, their particularity and the diversity of engagement that participants have when participating in them. Moreover, attending to the specific detail of memory events and sites helps to see not only how they work, but also the extent of their reach and the fixity (or not) of who they might be able to include. Such attentiveness to place and event becomes important politically when we consider who is rendered as "other" in memory narratives and what may be the implications of this "othering", for example in questions of social justice, post-conflict reconciliation, multicultural inclusion or the political transformation of the State. For example, in Australian military commemorative events, the formal recognition of Indigenous service people has only recently begun to occur, demonstrating how narratives can be transformed, but also how hard-fought and delayed such recognition can be. ${ }^{42}$ Accordingly, four aspects of commemorative events and the way they are related to the politics of memory and identity will be further explored, with an emphasis on the importance of empirical approaches that attend to the specificities of place and event.

First, as part of annual calendars of national events, commemorations reinforce specific narratives through regularity and the repetition of particular elements from which they are comprised. The opening notes of familiar music, for example, or sounds that punctuate the rhythm of events, such as gunshots or murmured speech, signal when the visitors are engaged in a ritual and lead them forward from moment to moment. These rituals are enacted by way of bodily gestures - gathering, standing, bowing, placing hands over hearts - that layer their meanings into physical memory. ${ }^{43}$ Particular days may be looked forward to or dreaded, because the same day on previous years could have conditioned the understanding of the event in general. Anticipation is one way to understand how

39 Robin Wagner-Pacifici, "Reconceptualizing Memory as Event", in Anna Lisa Tota and Trever Hagen (eds), Routledge International Handbook of Memory Studies, Routledge, London, 2015, p. 23.

40 Ibid.

41 Ibid.

42 Ben Wellings and Shanti Sumartojo, "Anzac, Race and Empire: Memorialising Soldiers and Warriors in Australia", in Shanti Sumartojo and Ben Wellings (eds), Commemorating Race and Empire in the First World War Centenary, Presses Universitaires de Provence, Marseille, 2018.

43 Paul Connerton, How Societies Remember, Cambridge University Press, Cambridge, 1989, p. 72. 
commemorative events are articulated and interpreted. For example, in the case of Anzac Day, the annual day of national remembrance in Australia, and its ceremony of Dawn Service, "anticipation is built publicly in the days leading up to [the event] with an increased intensity of media coverage, and at a personal level by the preparations and bodily experiences of collective movement to memorial sites immediately before the commemorative ritual". ${ }^{44}$ The emotional terms in which the event is remembered in previous years - perhaps as moving, sad, boring or annoying - coalesce to form part of how it is understood in general, and are often imbricated in visitors' stances towards the narratives it promulgates. These regular, bodily performed rituals act to connect participants together in commemorative moments, and provide a sense of connection to people they imagine have performed or will perform the same ritual in the past or future. Those points of connection are crucial in the formation and maintenance of (imagined) national communities. ${ }^{45}$

The peculiar temporal effect of these events' repetitive nature, however, is not limited to how they build foreknowledge and anticipation each year. It also shows how commemorative events are as much about the future as they are about the past. They are a way for the State and participants to speak forward to other people who will come in the future and experience what is thought to be significant in the present. Middleton and Brown suggest that this focus is akin to thinking about "imaginary futures in the past". ${ }^{46}$ The necessity for forward thinking helps us to understand why governments invest in memorials, museums, repeated rituals, education and many other forms of national historical representation and experience in order to reinforce and protect particular memories and particular ways of remembering. Linking the past to the present and having the populace connect with that narrative reinforces the collective adhesiveness of national identity narratives - the so-called "stickiness" mentioned previously. Official remembering is a way to reach into the future, to try to legitimate certain perceptions by making them difficult to forget and by leaving material and immaterial remains to shape the understandings of others. This organized remembering includes the rhythms and material and sensory elements of regular commemorative events.

The second notable aspect of commemorative events is that they provide an opportunity for public reflection on matters of shared identity. To that end, they are usually accompanied by widespread media coverage. These are moments in which chosen memory narratives are certainly used to buttress national identity, but there might also be openings for challenge, contestation or transformation. For example, journalist Paul Daley treated Anzac Day 2016 as an opportunity to

44 S. Sumartojo, "On Atmosphere and Darkness", above note 38, p. 7.

45 Benedict Anderson, Imagined Communities: Reflections on the Origins and Spread of Nationalism, Verso, London, 1983.

46 David Middleton and Stephen D. Brown, "Experiences and Memory: Imaginary Futures in the Past", in A. Erll, A. Nünning and S. B. Young (eds), above note 5. 
point out what was not remembered during the "carnival of commemoration". 47 Daley emphasized the silence on many aspects of conflict, such as the death or disfigurement suffered by combatants and others and the large sums spent reinforcing commemorative narratives. Most notably, Daley and others have pinpointed the politics of memory of Anzac narratives and how they obscure national recognition of the frontier wars and violence against Indigenous people that was and is at the heart of the Australian colonial project. Historian Mark McKenna, for instance, has argued that Anzac Day is a form of political displacement which salves public unease and distracts from the unresolved and ongoing dispossession of Indigenous peoples from their land. ${ }^{48}$ Relatedly, Drozdzewski and Waterton have questioned how and whether the Anzac narrative is elastic enough to stretch to encompass Australia's increasingly diverse population. ${ }^{49}$ Yet, they also point out that deviation from the accepted public narrative is scarce and that vilification ensues from such dissonance. Thus, the regular commemorative moment of Anzac Day enables an ongoing debate and shaping of public engagement with historical narrative in Australia.

A third aspect is the way in which commemorative events draw together and invite people to participate in a collective practice. This collaborative remembrance happens in two distinct ways. The first is the knowledge that many others are commemorating the same event. For example, Anzac Day in Australia occurs every year on 25 April, when Dawn Service events are held around Australia and the world. The coming together of citizens is demonstrated and made visible by rolling coverage on the national public Australian Broadcasting Corporation network, which begins with the local metropolitan Dawn Service and the official national ceremony at the Australian War Memorial in the capital city of Canberra. Coverage continues throughout the day, following the rising sun at Australian memorial sites in Gallipoli (Turkey) and Villers-Bretonneux (France), and various locations in Southeast Asia. This span of coverage means that Anzac ceremonies are on television from 5.30 a.m. to around 3 p.m., contributing to a sense of collectivity made manifest through collective participation and/or spectating of the ceremonies.

A final aspect of collectivity that requires attention takes place at the ceremonies themselves. The experience of gathering in the pre-dawn light, standing in a large group waiting for the ceremony to begin, and murmuring the same words or singing the same songs with a crowd that can number into the

47 Paul Daley, “Australia's Anzac Carnival of Commemoration Leaves Some Things not Talked About", The Guardian, 25 April 2016, available at: www.theguardian.com/australia-news/postcolonial-blog/2016/apr/ 25/australias-anzac-carnival-of-commemoration-leaves-some-things-not-talked-about (all internet references were accessed in July 2019).

48 Mark McKenna, “Anzac Day: How Did It Become Australia's National Day?”, in Marilyn Lake and Henry Reynolds (eds), What's Wrong with Anzac? The Militarisation of Australian History, Sydney, University of New South Wales Press, 2010, p. 112.

49 Danielle Drozdzewski and Emma Waterton, "In Remembering Anzac Day, What Do We Forget?", The Conversation, 20 April 2016, available at: https://theconversation.com/in-remembering-anzac-day-whatdo-we-forget-57629. 
tens of thousands is powerful for many people. ${ }^{50}$ At these moments, the imagined national community is immediately evident and visceral, with groups of people around the country sharing experiences that are made more significant through their collective nature. Scenes of this connection are beamed nationally via media broadcasts. However, at the same time, the bodies of others can diminish or complicate the rhetorical impact of the event, for example as their umbrellas block the view or the rustling of their coats or their murmured conversations make it difficult to hear the speeches. The point here is that because Statesponsored commemoration is so often experienced collectively, the particular affordances of being in a group must become a part of the understanding of conflict and trauma and how commemoration matters to people and influences particular configurations of perception.

Commemorative narratives are often understood in the abstract in relation to feelings of pride or grief, narratives about individuals that come to symbolize whole groups, or exemplars for so-called national characteristics. Cumulatively, however, they are always experienced as a particular set of material, sensory and discursive conditions. Commemorative events blur State-sponsored memory and narrative with the particular, lived conditions of which they are comprised. Mitchell identifies an implication for the politics of memory and identity related to this when she remarks:

The repetition engaged in various commemorative events and rituals ... is crucial in blurring the differences between individual interpretations of events, and creating a single, highly idealized, composite image. This image then forms the generalized social framework for future recollections, and through time, individual memories tend to conform and correspond with this composite. ${ }^{51}$

When visitors attune to the bodily and sensory experience of memory sites and events, certain meanings can be parsed in terms of individual experience, an approach that opens up potential for them to be reimagined. This experience then "shows how both the representational and the more-than-representational are important elements in the creation and maintenance of national identities, and recognises this as related to the interaction between people and their built environments". ${ }^{52}$ For example, while Anzac Day might be presented in terms of its invocation of a particular historical discourse, the experience of actually attending a ceremony can be chilly, uncomfortable and tiring. As the experiences of such events have shown, there might be moments of reflection and of engagement with collective memory, but there are also cold feet, tired eyes and sore backs from waking early and standing for an hour in the pre-dawn autumnal weather. ${ }^{53}$ Thus, the connection between memory and identity might not be as

50 S. Sumartojo, "On Atmosphere and Darkness", above note 38.

51 K. Mitchell, above note 10, p. 443.

52 S. Sumartojo, "Commemorative Atmospheres", above note 38, p. 5.

53 S. Sumartojo, "On Atmosphere and Darkness", above note 38. 
determined and monolithic as the State would sometimes have us believe, but instead is conditioned and intertwined with the fleshy, affective and individual engagement of the people through whom it is meant to do its work. This engagement becomes even clearer if one looks beyond official and Statesponsored memory sites to those of the everyday.

\section{Remembering and the everyday}

In scrutinizing the relationship between memory and identity, the authors have thus far focused on official locations and events of memory. In both cases, the spatiality of memory, or the "a-where-ness" of memory, is paramount. ${ }^{54}$ The place of memory, its physical locale linking memory to territory, and the metaphoric and atmospheric places of memory created through the performance and practice of commemorative events rely on the bounding of memory to specific geographic places ${ }^{55}$ Routine commemoration and official designation imbue these places with significance to the nation through things like monuments, memorials and historical plaques. ${ }^{56}$ Such places often rely on official and State-led designation to coordinate largescale and ongoing acts of remembrance, testifying to the importance of what is being remembered about the nation, as much as where it is being remembered. In this final section, the authors shift their focus to the everyday, which encompasses the places, landscapes and spaces of our daily routines, and can include streets, commercial areas, parks, public squares and playgrounds. These are locations where we work, live and recreate; we also move between, in and through them, sometimes at speed while we are hurrying from one daily task to the next. They are also the types of spaces and places that we innately and intimately know - we can navigate them (almost) without thinking because we rely on our memory of them. Memory resides in such spaces and places, often without us realizing the extent of our vernacular expertise. Because movements and thoughts in these spaces and places are often directed not towards commemoration or remembrance but towards our daily routines and tasks, the operation of a politics of memory may not be necessarily apparent or overt. Yet, the streetscapes, parks and public spaces that we traverse daily nonetheless portray the nation's memories. ${ }^{57}$

Overlaying a consideration of the everyday as a location where memory and identity share a symbiotic and intricate relationship is a focus on small-scale acts of commemoration. Small-scale commemorations may include, but are not limited to, street names, plaques affixed to buildings or into the pavement, remnants of war and conflict such as bullet holes or shrapnel, and candles and flowers. Thus, our

54 B. S. Osborne, above note 8, p. 39.

55 Pierre Nora, "Between Memory and History: Les Lieux de Memoire", Representations, No. 26, 1989.

56 Alan Gordon, Making Public Pasts: The Contested Terrain of Montreal's Public Memories, 1891-1930, McGill-Queen's University Press, Ontario, 2001, pp. 16-17.

57 Danielle Drozdzewski, "Encountering Memory in the Everyday City", in D. Drozdzewski, S. De Nardi and E. Waterton (eds), above note 4, p. 19. 
everyday focus permeates not only the type of space but also the implicitness of the form of commemoration and remembrance in those spaces. Indeed, the representation of the nation's past in the everyday matters, a point vividly evidenced by the recent eruption of violence in response to attempts to remove the statue of Confederate general Robert E. Lee in Charlottesville, Virginia. ${ }^{58}$ In other words, memory intersects into our everyday lives; it has longevity and adhesion. The politics of identity prompt further questions, such as how the use of memory in everyday spaces and places may express political hegemony, and whether there are spaces of/for resistance. In addition to considering these provocations, examples of material commemoration "need" to be visited and/or actively remembered to maintain their impact. In theorizing sites of war-related memory, for example, Jay Winter has argued that such activities and performances are "crucial" for maintaining the force and meaning of such sites, along with the related impulses to present and conserve them. ${ }^{59}$ Similarly, James Young contends that without processes of socialization, "monuments are of little value, mere stones in the landscape". ${ }^{60}$ As an example, it is useful to consider whether passing a memorial on a daily basis qualifies as activity, particularly if one does not stop to look at the memorial, but nevertheless knows that it is there.

In investigating small-scale memorialization in the everyday streetscapes of Warsaw and Berlin, for example, it was found that residents of those cities would not necessarily stop at the memorials, but they did note an "a-where-ness" of their location and what was memorialized there. ${ }^{61}$ In arguing that "memory is always 'available' but only made 'accessible' when faced with sensual cues", Muzaini suggests that active remembrance may take many forms, and that these can be unspoken, affective and internal. ${ }^{62}$ Moreover, he contends that "everyday practices [of remembrance] often take place at the confluences of multiple subjectivities, multiple affects, multiple temporalities". ${ }^{63}$ Similarly, in his examination of how memories of war intersect with the identities of young Falkland Islanders, Benwell has argued that an assemblage of memory mediums (post-war landscapes, school curricula, dialogues with adults and formal commemorative events) work together to transmit national identity. ${ }^{64}$ At Victoria Dock, a residential development in Hull, United Kingdom, Atkinson has also shown how a focus on everyday markers of memory, in the form of maritime street names, ship anchors and pavement mosaics, enabled a "rethinking of

58 Hilda E. Kurtz, "Introduction to the Special Forum: In the Aftermath of the Hate Rally in Charlottesville", Southeastern Geographer, Vol. 58, No. 1, 2018.

59 Jay Winter, "Sites of Memory and the Shadow of War", in A. Erll, A. Nünning and S. B. Young (eds), above note 5, p. 63.

60 James E. Young, The Texture of Memory: Holocaust Memorials and Meaning, Yale University Press, New Haven, CT, 1993, p. 2.

61 D. Drozdzewski, above note 57.

62 Hamzah Muzaini, "On the Matter of Forgetting and 'Memory Returns", Transactions of the Institute of British Geographers, Vol. 40, No. 1, 2015, p. 110.

63 Ibid., p 110.

64 Matthew C. Benwell, "Encountering Geopolitical Pasts in the Present: Young People's Everyday Engagements with Memory in the Falkland Islands", Transactions of the Institute of British Geographers, Vol. 41, No. 2, 2016, p. 129. 
memory as a less bounded and continually reconstituted process". ${ }^{65}$ Taken together, these scholars show that engagement and experience matters in how we interact and continue to interact in everyday spaces and places.

What these studies contribute is their consideration of memory beyond representation, which is precisely what we, and other authors, argue for in our orientation towards experience. ${ }^{66}$ Atkinson has conceptualized this more-thanrepresentational leaning as a movement towards a "topology of memories ... [that is] continually reconfigured by new eruptions of memory". ${ }^{67}$ Thinking about the (re)production and transmission of memory through an everyday lens decentres a more orthodox tendency to fix memory to particular events and days, encompassing certain activities of remembering. Rather, remembrance and commemorative practice in the everyday streetscape may be simultaneously discreet, contested, multiple and exemplified through multi-level performances. For example, speaking about the Tchorek Tablets (commemorative plaques embedded in the walls of buildings in Warsaw) that commemorate Polish victims of Nazi aggression in Warsaw during the Second World War, one study participant noted that the Tablets "are more connected to the reality/everyday life. It isn't a place where we go to visit a certain monument, but we pass next to it every day, it's slightly different feeling." 68

Key to the argument here is that an apparent lack of activities to signify remembrance does not and should not necessarily equate with the devaluation or forgetting of memory, since remembrance and its performance(s) may differ depending on place. If, then, memories of war in the everyday landscape can be experienced, (re)produced and maintained with and without coordinated collective ritual, what are the implications for a politics of memory and identity in this context? Markers of a nation's past selectively represented in everyday streetscapes can be "ostensibly visible, quintessentially mundane, and seemingly obvious". ${ }^{69}$ In their recent book The Political Life of Urban Streetscapes, Reuben Rose-Redwood et al. comment that "a site of everyday routines and fleeting encounters, the 'street' can also become a place of memory". ${ }^{70}$ Think, for instance, how many streets in Italy are named Via Garibaldi; in Poland, Aleja Armii Krajowej; or in Australia, after the Anzacs. The naming of these streets after important battles, armies and wartime heroes is no coincidence. Further, the placement of these street names, often as large thoroughfares in and out of the city centre, testifies to the overt use of a politics of memory.

65 David Atkinson, "Kitsch Geographies and the Everyday Spaces of Social Memory", Environment and Planning A: Economy and Space, Vol. 39, No. 3, 2007, p. 537.

66 Divya Tolia-Kelly, "Landscape, Race and Memory: Biographical Mapping of the Routes of British Asian Landscape Values", Landscape Research, Vol. 29, No. 3, 2004; O. Jones, above note 6.

67 D. Atkinson, above note 65, p. 537.

68 Participant 34, 21 May 2014, in D. Drozdzewski, above note 57.

69 Maoz Azaryahu, "The Power of Commemorative Street Names", Environment and Planning D: Society and Space, Vol. 14, No. 3, 1996, p. 311.

70 Reuben Rose-Redwood, Derek Alderman and Maoz Azaryahu, "The Urban Streetscape as Political Cosmos", in Reuben Rose-Redwood, Derek Alderman and Maoz Azaryahu (eds), The Political Life of Urban Streetscapes: Naming, Politics, and Place, Taylor \& Francis, Derby, 2017, p. 1. 
In the post-war renaming of streets in Kraków, Poland, most of the inner city's street names reverted from their wartime German names to their pre-war Polish names. However, the newly installed Soviet regime chose to rename seven streets within the Krakow Old Town and its ring roads. ${ }^{71}$ The common intention of these new names was to explicate fascist failure and German's subjugation of the Poles, but the choice of location of these renamed streets, in the Old Town, expounds the usefulness of both name and location. For example, a large section of the ring road around the perimeter of the Old Town, along which trams and buses traverse, was renamed May Day (Święto Pierwszego Maja) - an important date in the Soviet calendar instituted to reinforce the collective experience and identity of workers in the socialist-controlled Soviet territories. This example shows how "decision-making procedures and the wider re-planning of the political geography and semiotic order of the city" influences the likely level of exposure to certain street names through their spatial positioning. ${ }^{72}$ When city inhabitants think about the transportation route they will use daily, they recall that street name, understand the significance of that name to the nation's history and repeat it (verbally or mentally). This repetition is part of a process of naming as norming, of what Azaryahu describes as the "ability [of street naming] to make a version of history an inseparable element of reality as it is constantly constructed, experienced and perceived on a daily basis". ${ }^{73}$ The astuteness of the spatial positioning of a certain street name can amplify how often that name is repeated, so one must also look past the discursive and structural in the everyday streetscape (that is, the production of naming the streetscape) and towards the (re)production and performative capacity of the everyday to implicitly reinforce certain political agendas and how they shore up consensus for a particular version of the nation's past.

Yet, strategic placement of a street name does not necessarily guarantee repetitive performance of that name. Part of the process of attuning to the experiential includes considering how people in those spaces receive and possibly also resist attempts to inculcate memory into the streetscape. ${ }^{74}$ An often-cited example of resistance to naming is Meyers' study of Zanzibar, in which he outlines how "under colonialism, many sardonic [place] nicknames became official" because few colonial officials spoke Swahili. ${ }^{75} \mathrm{He}$ points out that the names must be vocalized and heard in order to understand their full cultural

71 Danielle Drozdzewski, "Using History in the Streetscape to Affirm Geopolitics of Memory", Political Geography, Vol. 42, 2014.

72 R. Rose-Redwood, D. Alderman and M. Azaryahu, above note 70, p. 6.

73 M. Azaryahu, above note 69, p. 321.

74 James Duminy, "Street Renaming, Symbolic Capital, and Resistance in Durban, South Africa", Environment and Planning D: Society and Space, Vol. 32, No. 2, 2014; Joshua Hagen, "Theorizing Scale in Critical Place-Name Studies", ACME, Vol. 10, No. 1, 2011; Reuben Rose-Redwood, "From Number to Name: Symbolic Capital, Places of Memory and the Politics of Street Renaming in New York City", Social \& Cultural Geography, Vol. 9, No. 4, 2008.

75 Garth Andrew Meyers, "Naming and Placing the Other: Power and the Urban Landscape in Zanzibar", in Lawrence D. Berg and Jani Vuolteenaho (eds), Critical Toponymies: The Contested Politics of Place Naming, Ashgate, Farnham, 2009, p. 92. 
meaning. ${ }^{76}$ This experiential component, not deducible from map reading or archival research alone, allows for the detection of derision and apathy in audible cues. Kearns and Berg also explore speaking as a form of resistance in the pronunciation of the names of Maori places in New Zealand. They contend that "pronunciation can potentially be a form of resistance" because "speaking, in almost all circumstances, is a social act". ${ }^{77}$ The oral repetition of Maori place names, encompassing a diversity of "politically correct versions of pronunciation", may therefore have the cumulative effect of bolstering support for Maori identity politics in New Zealand. Duminy's Durban-based study provides a further example of resistance to the (re)inscription of street names after colonial subjugation. Interrogating the concept of symbolic resistance, Duminy summates that activities of resistance to street name changes in Durban, which included removing new street signs, the continued use of original street names and the generation of media discourse concerning the location of new names, were limited and thus demonstrated acceptance of the State's right to change names. ${ }^{78}$

At this point in the discussion it is useful to think through the acceptance of the right of the State to mark public space with markers of the nation's past. The power of the everyday setting, unlike specific commemorative locations and events that very obviously demarcate a specific narrative line, is that in linking national identity to cultural memory, the parks, streets and place names of local neighbourhoods have greater potential to slip under the radar as spaces and places of political purpose. For example, in the major Australian cities of Sydney and Melbourne, where the authors reside, numerous street and place names commemorate colonial history. Elizabeth, William, George and Victoria are all popular toponymic markers of colonization. For the most part, these names remain unquestioned because they appear largely unequivocal. Likewise, statues of James Cook, Lachlan Macquarie and Arthur Philip are common; yet, there is a nascent discourse among non-Indigenous Australians about these men's role in the decimation of the Indigenous population's post-European arrival in Australia. ${ }^{79}$ The resonance of such voices remains minimal in a political landscape where discussions on republicanism have failed to gain political currency, and where Australia's largest symbolic wartime commemorative event still narrates the heroic birth of a nation on the foreign battlefield of Gallipoli, while failing to narrate as loudly the tactical British decision to send Anzac troops to a doomed battlefront. Significantly, the democratic birth of the nation took place thirteen years prior to that battle at Federation.

76 Ibid., p. 86.

77 Robin A. Kearns and Lawrence D. Berg, "Proclaiming Place: Towards a Geography of Place Names", in L. D. Berg and J. Vuolteenaho (eds), above note 75, p. 158.

78 J. Duminy, above note 74.

79 "Captain Cook Statue Vandalised in Melbourne before Australia Day", The Guardian, 25 January 2018; Christopher Knaus, “No Pride in Genocide': Vandals Deface Captain Cook Statue in Sydney's Hyde Park", The Guardian, 26 August 2017; "Statues Vandalised in Sydney's Hyde Park", The Australian, 26 August 2017. 
Marking physical public space, combined with the domination of certain political agendas in everyday discourse, provides political elites with access to the populace in seemingly mundane and ordinary spaces and places. In these settings it would seem that dissenting voices occupy very small corners of the discussion, which is otherwise dominated by an unwitting or indifferent acceptance of the instituted norm.

\section{Conclusion}

The selected representations of a nation's past, displayed publicly, are mediated and remembered through the contexts of the societies in which we now live, but also through their histories. Halbwachs argued that remembering is an inherently social process: we not only recall a certain event, place or person, but also contextualize that memory within a certain time, with groups of people or places. ${ }^{80}$ Most crucially, when we remember, we recall from our position in the present, and present-day contexts have the ability to influence what is recalled and the relevance and/or importance of a specific memory. When it comes to the concept of the politics of memory, the portrayal of national narratives through memorials and monuments should not be conceived merely as a "material backdrop" 81 from which a story is told; rather, public representations of memory should be perceived as an integral part of a nation's story of remembering, commemoration and identity-making. In addition to its particular social and temporal aspects, "commemorative activity is inescapably political", 82 which means that it always includes and excludes people, and has always been a powerful means of defining the "other" in national terms.

In this article, the authors have sought to situate their perspective in the encounter between the material and discursive artefacts of shared memory and the individuals who do the remembering. As such, when State-sponsored memory comes to "matter", there is a need for attention to the experiential. This approach, supported by the authors, is fruitful precisely because it allows us to step beyond the well-trammelled representative and discursive aspects of the memory of war, or its "material backdrop", and to see how the society perceives and makes sense of it in a range of settings. This aspect often goes unexamined in the bulk of accounts that attend to structural or discursive factors, even though, as Marshall remarks, "we use our senses to forge connections with our physical environment and develop our sense of place .... Remembrance, because it is experienced through the senses, is one such embodied state." 83

80 Maurice Halbwachs, On Collective Memory, University of Chicago Press, Chicago, IL, 1992.

81 Nuala Johnson, "Cast in Stone: Monuments, Geography, and Nationalism", Environment and Planning D: Society and Space, Vol. 13, 1995, p. 51.

82 Ben Wellings, Matthew Graves and Shanti Sumartojo, "Commemorating Race and Empire in the First World War Centenary", in Ben Wellings and Shanti Sumartojo (eds), Commemorating Race and Empire in the First World War Centenary, Presses Universitaires de Provence and Liverpool University Press, Aix-en-Provence, 2018, p. 8.

83 Debra Marshall, “Making Sense of Remembrance”, Social \& Cultural Geography, Vol. 5, No. 1, 2004, p. 38. 
Concurrently, however, it is not argued that such official modes of remembering as monuments, museums, and commemorative days and events should be disregarded, because they are powerful and often well-resourced anchor points for narratives regarding conflict and nation that circulate widely. In attending to the individual and experiential in official sites and events, as well as in more banal everyday settings, there is a need to show how such narratives are actually taken up in complex ways that do not somehow sit apart from other aspects of our lives. Put differently, memory is integral to how we understand ourselves and our worlds, and this includes those aspects that might overlap with State interests. It follows that in order to fully grasp the impact that nation-based and collective memories of war might have in cohering people socially and culturally, there is a need to see them as entangled with our sensory, experiential, idiosyncratic and quotidian individual lives. This could provide a route to understanding how one might feel a part of the nation, and come to have a sense of belonging to it - and also how conventional or existing understandings might be changed or resisted. In their account, the authors have attempted to locate the nation in how societies feel about and feel in it, ${ }^{84}$ and how this exceeds the limits of the discursive vocabulary that official channels provide. This may help us to reimagine how memory "matters" when it comes to national belonging, and where the politics of memory might be disrupted, challenged or transformed to adopt more inclusive and just forms. 